\title{
REDAKSIONEEL
}

\section{Die jaarvergadering}

Op 15 Junie het die GTV in die Moria Tehuis vir bejaardes op Krugersdorp vergader. Ds. C. Hattingh en die bestuur het die vergadering gul onthaal en so bygedra tot 'n baie geslaagde dag.

Die voordragte en inleidings tot die besprekings beslaan die grootste gedeelte van hierdie uitgawe. Die aktuele onderwerp het groot belangstelling geniet en 'n lewendige bespreking uitgelok. Dit was ook die eerste vergadering waar studente van Hammanskraal gaste van die Hoofbestuur was. Die studente van Potchefstroom woon reeds enkele jare die jaarvergadering by. Daar was ook ' $n$ paar predikante van die jong kerke teenwoordig. Dit is verblydend om hierdie bewuswording van ons gemeenskaplike roeping ten opsigte van die gereformeerde teologie op te merk. Die feit dat die teologie as sodanig sterk belangstelling uit geledere van die jong kerke begin trek, is ' $n$ nuwe mylpaal. Mag die GTV ook in hierdie verband diens lewer.

Die verkiesing van die hoofbestuur het volgens konstitusie op hierdie vergadering plaasgevind. Verskillende lede van die vorige hoofbestuur het hulle nie weer beskikbaar gestel nie. Die leiding van die GTV is toevertrou aan dr. C. J. Malan (voorsitter), dr. M. Venter (onder-voorsitter), ds. J. J. de Jager (sekretaris), ds. A. J. du Plessis en ds. A. B. Helberg. Die broeders word sterkte toegewens vir hulle taak.

Die volgende finansiële verslae is met hartlike dank aan ds. C. J. H. Venter, die uittredende sekretaris en mev. S. A. Louw wat die administrasie van In die Skriflig behartig, ontvang en aanvaar.

Ontvangste en betalingsrekening vir die rekenpligtige tydperk geeindig 31 Mei 1976:

Fondse beskikbaar op 1.6 .75

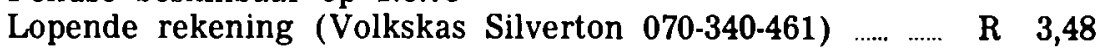

Spaarrekening (Volkskas Silverton 07-9341-037) ................ R218,96

Ontvangste

Daggeld

R146,00

Rente (30.1.75-30.1.76)

R 11,76

Totale fondse beskikbaar

R375,20

Min uitgawes

Sprekers jaarvergadering 1975

R110,00

Skryfbehoeftes, pos- en tikgeld R 44,65

Fondse beskikbaar 31.5.76

$\mathrm{R} 154,65$

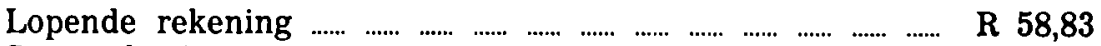

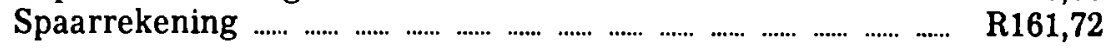


In die Skriflig

Staat van inkomstes en uitgawes soos op 20 Mei 1976:

Inkomstes

Aan saldo op 25.2.76

R 704,08

Aan intekengeld

1107,06

Aan donasies

1152,00

Aan saldo in spaarrekening

980,10

R3 943,24

Uitgawes

Per drukkoste Maart-uitgawe

R 536,97

Per diverse

34,25

Per saldo in lopende rekening

2391,92

Per saldo in spaarrekening

980,10

R3 943,24

Aan saldo in lopende rekening

R2 391,92

Aan saldo in spaarrekening

980,10

Totaal

R3 372,02

\section{Sentralisasie en pluralisme}

In hierdie uitgawe verskyn ook 'n artikel van prof. A. H. Murray van die Universiteit van Kaapstad. Die artikel is o.i. prikkelend. Ons betuig hartlike dank aan ds. J. C. Kotzé van die N.G. gemeente De Aar wat aan ons 'n bandopname beskikbaar gestel het waardeur die lesing in druk kon verskyn.

Die artikel prikkel in die eerste plek tot rekenskap van die ineengeweefdheid van politieke en kerklike tendense in die geskiedenis ook ons eietydse. Die berugte St. Bartholomeusnag waarin duisende Hugenote hulle lewe gelaat het, is dikwels toegeskryf aan 'n aksie van die koningin moeder, Catharina de Medici, gebore uit Roomse fanatisme.

Die artikel toon oortuigend aan dat die gebeure regstreeks in verband gebring moet word met die strewe na 'n gesentraliseerde Frankryk onder die absolute heerskappy van een despotiese vors. Die heersende stelsel van plurale gebiede (met die bekende Hugenote stede en mindere leiers of magistrate d.w.s. „owerhede”) het die ontwikkeling in die weg gestaan.

In die tweede plek gee die artikel begrip vir die destydse plurale regeringsinstelling wat in die gereformeerde kerkregeringstelsel van die Dordtse Kerkorde van 1619 beliggaam is. Die plurale tradisie het in mindere of meerdere mate erfenis geword van die Afrikaanse kerklike inrigtinge in Suid-Afrika. 'n Mens herinner jou nog goed hoedat tot nie so lank gelede nie op die sinodes en klassisse ernstig gewaak kon word vir die „selfstandigheid", outonomie”, „eie 
roeping en taak" en "eie verantwoordelikheid" van die plaaslike kerk en kerkraad - en selfs vir die eie roeping en vryheid van elke ouderling binne die gemeente. Maklik is sake wat ter klassis of ter sinode gevoer is, terug verwys. Vandag is die neiging egter om die dienste van ouderlinge (en diakens) eenvormig te skematiseer en dikwels voor te skryf; om in gemeentes dissipline af te dwing met die sambok waarop geskryf staan: „Die sinode het besluit”; om klassikale of visitasie "riglyne" en voorskrifte in die kerke vas te lê en in te voer; om met ' $n$ argument dat iets van ,algemene belang" is, 'n saak ter tafel te neem en art. 30 K.O. uit te skakel, ens. Kortom, die plaaslike vryhede en selfstandighede (plurale) word geleidelik weggebrokkel om die behoefte aan sentralisasie, eenvormigheid en enersheid te bevredig. Die behoefte word al sterker gevoel dat die ,sinode" as 'n gesentraliseerde struktuur, meer dikwels moet vergader, omdat die plurale gesaginstelling net nie meer as verteenwoordigend of effektief gesien kan word nie. Die artikel van prof. Murray en die bespreking van grondleggende reformatoriese dokumente werp derhalwe merkwaardige lig op ons wegbeweeg van destydse denkpatrone onder invloed van eietydse sentralisasie- en ekumenistiese skemas.

Aan die P.U. vir C.H.O. was die studentelewe ook geskoei op 'n konstitusie wat ruimte gelaat het vir die pluralisme (wat volgens prof. Murray tipies is van en eie aan die protestantse erfenis en begrip van individuele vryhede en regssoewereiniteit). Dit is my meegedeel dat dit tans nie meer die geval is nie, maar dat ook daar 'n gesentraliseerde stelsel ingevoer is.

Hierdie uitgawe verskyn in tye waarin daar heelwat onrus en selfs onluste woed onder hetrogene volks- en bevolkingsgroepe wat hulle na die Britse imperiale drang tot sentralisasie in „een" SuidAfrika bevind. Aan die een kant word die beleid van afsonderlike state (pluralisme) ontwikkel en word die Transkei eersdaags onafhanklik. Vir baie mense wat in die Britse tradisie en in terme van „unifikasie" geskool is, hou dit 'n skok in. Vir ander wat ook ",pluraal" kan dink, hou dit 'n gesonde „reformasie”, 'n terugkeer tot die feite van die vorige eeu voor 1875 en tot die begrippe van die hervormers en Hugenote in.

Die probleem van allerlei identiteite (om die sg. "stedelike Bantoe" maar net uit te sonder) roep egter nog om 'n oplossing. Dit is duidelik dat die moderne sosialistiese gesentraliseerde beginsel van „een-man-een-stem" nie die antwoord bied nie. Lê die antwoord nie ook daarin dat daar polities weer na die hervormers en Hugenote van die sestiende eeu geluister moet word nie? Het die pluralisme binne eenheid, die beginsel agter die Dordtse Kerkorde van 1619, nie ook polities vir Suid-Afrika iets te leer nie? Lê daarin nie ' $n$ veel beter basis vir regeringinstelling as in die Britse Westminister parlementêre patroon wat in sy wese 'n homogene entiteit veronderstel wat slegs deur prinsipiële partyverdelings beoefen kan word?

Kortom, van die organisasie van 'n studentelewe tot die ingewikkelde organisasie en instelling van moderne state en staat skyn 
daar in ons reformatoriese erfenis skatte te lê wat ook weer net op koestering wag!

Die artikel van prof. A. H. Murray roep ons inderdaad tot nadenke op. Indien bostaande pogings om te dink iets inhou, het juis die gereformeerdes en Potchefstroom in besonder ' $n$ brandende roeping om soos gedurende die volkskrisisjare in die verlede 'n koers aan te dui wat op reformatoriese beginsels gegrond is.

\section{Ekumenisme as begeleider van charismatiese?}

RES (Geref. Ekum. Sinode) Nuusbrief van Junie 1976 (RES News Exchange) haal dr. A. van der Heuvel, die skriba van die Sinode van Nederl. Herv. Kerk en vurige kampvegter vir die WRK en strukturele revolusie oor die wêreld aan. Hy beskou die ekumeniese en nuwe charismatiese beweginge wat oral in die wêreld uitslaan, simptome van 'n ,renewal movement. Neither, he said, aims at adding anything new, but only at recovering what is essential to the church. The ecumenical movement, in its search for the unity of the church and of humanity and its exposure of the socio-political sins of groups and nations, he saw just as much movement of the Spirit as the charismatic movement". Hier word die materiële en gesekulariseerde verheerlik as evangelie.

Dieselfde RES NE vermeld dat Rev. F. MacDonald van Cumbernauld in die Sinode van die Free Church of Scotland gewys het op die identiteitskrisis wat Engeland beleef: 'n toenemende sekularisme waarin die mens norm en sy materiële node prioriteit nr. een geword het verkeer in konflik met 'n nog sterk hoewel oppervlakkige wil om Christelik te bly. ' $n$ Meerderheid jeugdiges glo in God. Onder hulle doen ' $n$ meerderheid nog mee aan kerklike aktiwiteite. By weinig van hulle kom egter 'n persoonlike, oortuigde oorgawe aan Christus voor. „To become a consistent Humanist, one should become a Marxist. To become a consistent Christian means a total submission to the authority of Jesus Christ in the law and the Gospel and the adoption of an holy lifestyle of worship and caring".

Die kerk loop graag agter politici en mode aan. „Even the Church, we fear, in its obsession to be fashionable, rather than faithful, is in danger of opting out of its prophetic role". Hoewel maklik anders gedink word, is dit so indien die „,church only speak the Word of the Lord, more people will be willing to listen than we expect... The Church has lost spiritual power and influence" omdat dit van die evangelie weggeneem en dinge bygevoeg en die evangelie geisoleer het.

\section{Ekumenisme as triomf vir metodisme?}

Dit word vandag almeer duidelik dat die ekumenisme en horisontalisme 'n „veranderde" "hernude" of liewer „vervulde" metodisme is. Die kerkbegrip is dieselfde: bloot struktureel as 'n wêreldwye vereniging. Hulle humanistiese uitgangs- en doelpunt is dieselfde: Pelagius en die hooggeroemde humanisme waarvan Van der Heuvel melding maak. Hulle evangelie-inhoud is gerig op 'n "social gospel". 
In Suid-Afrika lyk die propagandiste baie dieselfde: die sendelinge van Sendinggenootskappe het die social gospel in die vorige eeu gedra; toegewyde fanatiese propagandiste uit kerklike en sendingkringe soos Van der Heuvel in die NHK, Vercuyl, Mulder, Schuurman. Van der Veen e.a. in die GKN. Hulle loop maklik by die "sonde" in eie kerk en lewe verby, maar meet saam met sosialistiese politici 'n paar sosio-politieke "sondes" uit. Die name van die sondes is kapitalisme, rassisme, seksisme en konserwatisme. Die propaganda het dus nog steeds dieselfde eensydige filantropiese gerigtheid 'n produk van die rennaissance humanisme en naturalisme.

\section{Gaan ons die identiteitskrisis binne?}

Hierdie gedagtes mag ook in ons eie land en geledere sy kop uitsteek. Die humanisme en naturalisme is ook in Suid-Afrika vir baie ' $n$ religie. Talle van ons mense wil soos MacDonald aandui, probeer in die mode wees en sing op die klank af in die wêreldkoor saam of probeer hulle wysie improviseer.

Die agenda van die jongsgehoue G.E.S. is oulik maar doeltreffend gevoer met die dinge wat vandag mode is. Die orkesbegeleiding van onluste-musiek het die Sinode hom veral op SuidAfrika laat rig. Konfessionele eenheid word nog teoreties genoem en veronderstel, maar is nie baie meer as 'n afspringplek om by die sosio-politiese temas uit te kom nie.

$\mathrm{Jy}$ is egter te midde van alles soos 'n vlieg wat jou in die waren spinneweb al meer toespin, omdat jy met 'n nuwe eietydse kerkbegrip wat onder ons begin lewe gevang is in "strukture" as "kerk" - dominees en teoloë wat die "stem" van die „kerk" is. Sinode na Sinode en Ekumeniese Sinode na Ekumeniese Sinode word jy vaster gevang in die moderne ekumenisme, horisontalisme, reletativisme en strukturalisme.

Mag die besinning op die jongste GTV-jaarvergadering ons help om waarlik kerk te wees. 